\title{
Freedom through Compulsion
}

\section{The lesson of Alberta's great seat belt debate.}

\begin{abstract}
It was the spring of 1987. Canada/US free trade was all over the news, the loonie was novel and controversial, and Reagan was about to tell Gorbachev to tear down the Berlin Wall. But Albertans were focused on another issue entirely: Should we mandate the use of seat belts? Cars had featured seat belts since the 1950s, but their use in Alberta was optional. The debate had risen to a simmer. Now it had reached the boil.

Ontario had passed a seat belt law 10 years earlier, arguing it would save lives of drivers and pedestrians alike. (I remember as a boy learning the term "human missile"-an unbuckled person propelled through a windshield.) By 1987 every province had followed suit except Alberta and PEI. Opposition and backbench MLAs proposed a law here. The Alberta Medical Association pointed out it would save healthcare tens of millions of dollars annually. The police, accident reconstructionists and the Alberta Motor Association favoured a law. Polls showed Albertans split, with women in every age category and men under 40 in favour, and men over 40 opposed. As one MLA put it, "Everyone has a view, and in most cases a strongly held view, on this important subject."

The PC party was further divided between urban MLAs (for) and rural MLAs (mostly against). The urbanites gained enough ground that Bill 9, the seat-belt-mandating Highway Traffic Amendment Act, was tabled in March. Thus began a debate that Calgary Herald columnist Don Braid characterized as "some of the most alarmist sophistry ever heard in the Alberta legislature." Among the concerns raised by PC MLAs: Seat belts kill, so this law is like capital punishment. We should restrict alcohol instead. No one will follow the law. Seat belts stop bus drivers from helping old ladies. People can contract AIDS from having sex; should we control sex too? Jack Ady, Cardston MLA,

suggested that seat belt laws could increase rates of child abuse. Taber-Warner MLA Robert Bogle spoke for many when he said he preferred education to "the legislative hammer."

Other MLAs cited studies showing that collisions resulting in burning or submerged cars comprise less than half of 1 per cent of accidents, and that wearing a seat belt was no guarantee of death in such cases anyway. They showed how hundreds of deaths in Alberta would have been prevented had seat belts been worn, and how safety education proves less effective than laws. Despite the PCs' internal divisions, Bill 9 passed. In 1988, the first year of Alberta's seat belt law, traffic injuries dropped 5 per

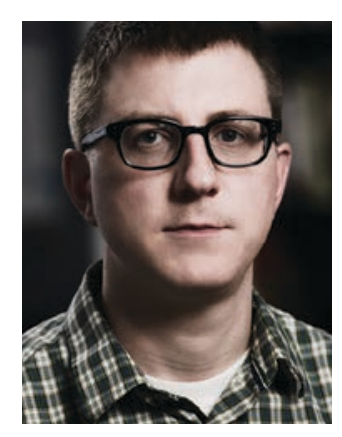
cent and deaths fell 9 per cent-this even though the number of collisions actually rose. Before the law, some 25 per cent of Albertans wore seat belts; afterwards, 90 per cent did.

Calgarian Kim Maier was so incensed by the new law that he took to driving around with his seat belt hanging out his truck door, shouting at police. He was eventually given a $\$ 25$ ticket, and in court Maier argued his life, liberty and security of the person were being violated by a "police state." The law was upheld, then overturned by Court of Queen's Bench. Braid called the latter "a great victory to Tories who view the seat belt as a communist plot." The law was reinstated by Alberta's Court of Appeal in 1989.

It's now 2014. Unexamined biases, anecdotal evidence, cynicism, fear and plain old ignorance can still threaten our health. But fastening one's seat belt is now utterly normal in Alberta, as is wearing a motorcycle helmet, using a child safety seat or taking a cab instead of driving drunk. Hundreds of Albertans are alive and unmaimed today because of mandatory seat belts. Maybe this includes you or me. A law that compels us to behave wisely-and to consider the consequences of our actions on others-has actually enhanced our freedoms.
\end{abstract}

ALBERTA VIEWS STAFF

Publisher

JACKIE FLANAGAN

Business Manager/

Associate Editor

NAOMI K. LEWIS

Editor

EVAN OSENTON

Art Director

BEATE WICHMANN

Departments Editor DOUG HORNER

\section{Proofreader}

JOE WILDERSON

Circulation

ALLY MCCONNELL

Administration MEG BRAEM

On leave

BETH ED

Advertising Sales

MARY SAVAGE

4032435334

Toll Free 18772125334
SUBSCRIPTIONS In Canada: $\$ 29.99$ per year (includes GST). In US: \$50.00 CDN.

Mail cheque or money order, subscribe by phone or visit www.albertaviews.ab.ca.

ALBERTA VIEWS is published by Alberta Views Limited Partnership 208, 32023 Ave SW, Calgary, Alberta T2S 0J2 Telephone: 4032435334 Toll-free (in Alberta only): 18772125334 Fax: 4032438599

CONTENTS COPYRIGHT 2014. Written queries with article proposals should include the author's resumé, tear sheets and a self-addressed, stamped envelope. All requests for permission to reprint should be made in writing to the editors. Printed in Canada. GST Registration No. 89455 6307. ISSN No. 1480-3151.

PUBLICATIONS MAIL AGREEMENT NO. 40024877.

RETURN UNDELIVERABLE CANADIAN ADDRESSES TO: CIRCULATION DEPARTMENT, 208, 32023 AVE SW, CALGARY, ALBERTA T2S 0J2 